Journal of Economic, Business and Accounting (COSTING)

Volume 2 Nomor 1, Juli-Desember 2018

e-ISSN : 2597-5234

https://doi.org/10.31539/costing.v2i1.330

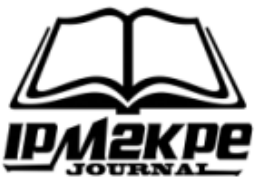

\title{
ANALISIS PENGARUH KUALITAS PELAYANAN TERHADAP KEPUASAN KONSUMENMENGGUNAKAN JASA PENGINAPAN
}

\section{ANALYSIS OF EFFECT OF SERVICE QUALITY ON CUSTOMER SATISFACTION USING HOSTELRY SERVICE}

\author{
Hariman Syaleh \\ Sekolah Tinggi Ilmu Ekonomi Haji Agus Salim Bukittinggi \\ harimansyaleh@yahoo.co.id
}

\begin{abstract}
Service quality is a way of working companies that try to hold continuous quality improvements to the processes, products and services produced by the company. This study aims to see the effect of the dimensions of service quality on customer satisfaction using lodging services at Kharisma Hotel Bukittinggi. The population of 1656 consumers and the sample in this study were 100 consumers. Data was collected through questionnaire deployment with Likert scale models then tested to the currency and reliability of the questionnaire. The data analysis technique used is the linear regression method. The results of this study are a). service quality Tangible (X1) dimension has a positive and significant influence on customer satisfaction at Kharisma Hotel Bukittinggi. $b$ ). the service quality of the Empathy $(X 2)$ dimension has a positive and significant influence on customer satisfaction at Kharisma Hotel Bukittinggi. c). the quality of service dimensions of Responsiveness (X3) there is a positive and significant influence on customer satisfaction at Kharisma Hotel Bukittinggi. d). service quality dimensions (Reliability) (X4) there is a positive and significant influence on customer satisfaction at Kharisma Hotel Bukittinggi. e) the service quality of the Assurance (X5) dimension has a positive and significant influence on customer satisfaction at Kharisma Hotel Bukittinggi.
\end{abstract}

Keywords: Service Quality, Consumer Satisfaction.

\begin{abstract}
ABSTRAK
Kualitas pelayanan adalah suatu cara kerja perusahaan yang berusaha mengadakan perbaikan mutu secara terus menerus terhadap proses, produk dan servis yang dihasilkan perusahaan. Penelitian ini bertujuan untuk melihat pengaruh Dimensi kualitas pelayanan terhadap kepuasan konsumen menggunakan jasa penginapan pada Kharisma Hotel Bukittinggi. Jumlah populasi 1656 konsumen dan sampel dalam penelitan ini sebanyak 100 konsumen. Data dikumpulkan melalui penyebaran kuisioner dengan model skala likert kemudian diuji ke valitan dan kehandalan dari kuisioner tersebut. Teknik analisa data yang digunakan adalah metode Regresi linear bergand. Hasil dari penelitian ini adalah a). kualitas pelayanan dimensi Bukti fisik (Tangible) (X1) terdapat pengaruh positif dan signifikan terhadap kepuasan konsumen pada Kharisma Hotel Bukittinggi. b). kualitas pelayanan dimensi Empati (Empathy) (X2) terdapat pengaruh positif dan signifikan terhadap kepuasan konsumen pada Kharisma Hotel Bukittinggi. c). kualitas pelayanan dimensi Daya Tanggap (Responsiveness) (X3) terdapat pengaruh positif dan signifikan terhadap kepuasan konsumen pada Kharisma Hotel Bukittinggi. d). kualitas pelayanan dimensi Keandalan (Reliability) (X4) terdapat pengaruh positif dan signifikan terhadap kepuasan konsumen pada Kharisma Hotel Bukittinggi. e) kualitas pelayanan dimensi Jaminan
\end{abstract}


(Assurance) (X5) terdapat pengaruh positif dan signifikan terhadap kepuasan konsumen pada Kharisma Hotel Bukittinggi.

Kata Kunci : Kualitas Pelayanan, Kepuasan Konsumen.

\section{PENDAHULUAN}

Kharisma Hotel adalah salah satu hotel berbintang dua yang terletak di pusat kota. Dimana lokasinya yang sangat strategis di jalan sudirman atau jalan utama kota bukittinggi merupakan pilihan yang sangat tepat untuk para pengunjung untuk bermalam di hotel kharisma ini. Selain lokasi yang sangat strategis kharisma hotel dekat dengan Tempat ibadah, Rumah sakit, Restaurant dan kuliner lainnya serta dekat dengan kantor kantor pemerintahan, ini sangat memudahkan untuk para pengunjung yang berwisata atau dalam perjalanan bisnis ke kota bukittinggi.

Permasalahan yang dihadapi oleh Kharisma hotel Bukit tinggi adalah jumlah tamu menginap yang mengalami fluktuasi selama tahun 2014. Hal ini dimungkinkan terjadi karena kurang lengkapnya fasilitas yang ditawarkan oleh kharisma hotel dan, receptionist kurang cepat dalam melayanitamu, karyawan dan staf kurang ramah dalam melayani pelanggan, dimana sebabsebab tersebut kemungkinan merupakan faktor kualitas pelayanan Kharisma Hotel Bukittinggi. Berikut adalah grafik Jumlah tamu menginap di Kharisma Hotel Buki ttinggi Tahun 2014- 2016.

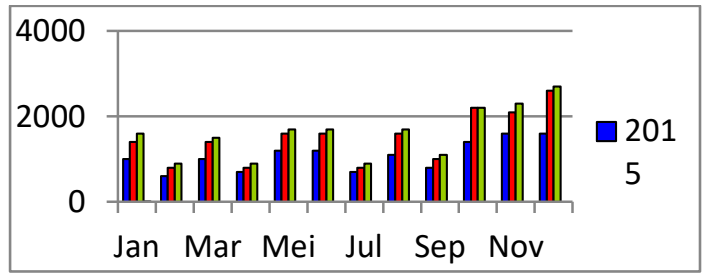

\section{Gambar 1. Grafik Jumlah Tamu Menginap}

Dari data diatas dapat dilihat bahwa grafik jumlah tamu yang menginap di kharisma hotel Bukittinggi mempunyai pola yang fluktuatif setiapbulannya jika dibandingkan antara tahun 2014 sampai dengan 2016. Tetapi ada beberapa bulan yang jumlah pengunjungnya mengalami peningkatan pada kurunwaktu tersebut yaitu pada bulan Januari, Maret, Mei Juni, Agustus , Oktober, November, dan Desember. Kejadian ini menjadi suatu pekerjaan bagi manajemen agar terusberupaya mengkombinasikan keunggulan keunggulan mereka untuk terus dapatmenarik minat konsumen, sekaligus mempertahankan konsumennya. Hal inidapat dilakukan dengan meningkatkan kualitas layanan yang diberikan karena inimerupakan salah satu faktor yang dapat menciptakan kepuasan pada dirikonsumen.Berdasarkan uraian di atas, maka diajukan sebuah penelitian denganjudul "Analisis Pengaruh Kualitas Pelayanan Terhadap Kepuasan KonsumenMenggunakan Jasa Penginapan pada Kharisma Hotel Bukittinggi”.

\section{Pelayanan}

Menurut Kotler (2007), service adalah setiap tindakan atau kinerja yang dapat ditawarkan satu pihak kepada pihak lain, yang pada dasarnya tidak berwujud dan tidak mengakibatkan kepemilikan sesuatu.

Kualitas pelayanan adalah merupakan kemampuan Perusahaan untuk memenuhi harapan-harapan pelanggan dan juga apabila pelayanan yang diterima atau dirasakan sudah sesuai dengan yang diharapkan, maka 
kualitas dipersepsikan baik dan dapat memuaskan pelanggan. Sebaliknya jika yang diterima lebih rendah daripada yang diharapkan, maka kualitas dipersepsikan buruk atau tidak memuaskan.

Kotler (2007).mengungkapkan bahwa kualitas pelayanan adalah suatu cara kerja perusahaan yang berusaha mengadakan perbaikan mutu secara terus menerus terhadap proses, produk dan servis yang dihasilkan perusahaan.

\section{Dimensi Kualitas Pelayanan}

Kualitas jasa pada umumnya tidak dilihat dalam konstruk yang terpisah, melainkan secara agregat dimana dimensidimensi individual dimasukkan untuk mendapatkan kualitas jasa secara keseluruhan. Terdapat lima dimensi utama kualitas pelayanan (sesuai urutan derajat kepentingan relatifnya) 1 . Keandalan Keandalan yakni kemampuan memberikan layanan yang dijanjikan dengan segera, akurat dan memuaskan Artinya para karyawan memberikan pelayanan yang sesuai dengan harapan pelanggan. 2. Daya tanggap Daya tanggap yaitu kcinginan para staf untuk membantu para pclanggan dan memberikan layanan dengan tanggap, yakni motivasi para karyawan dalam memecahkan masalah yang dihadapi pelanggan dalam menagunakan jasa 3 . Jaminan Jaminan mencakup pengetahuan, kompetensi, kesopanan dan sifat dapat dipercaya yang dimiliki para staf, bebas dari bahaya, risiko atau keraguan. Yaitu mengenai pengetahuan balk dari karyawan dalam menangani pertanyaan atau keluhan dari pelanggan 4. Perhatian Perhatian meliputi kemudahan dalam menjalin relasi, komunikasi yang balk, perhatian pribadi, dan pemahaman alas kebutuhan individual para pelanggan yaitu sikap karyawan yang menunjukkan perhatian yang tulus dalam melayani pelanggan. 5 . Bukti Fisik Tampilan fisik meliputi fasilitas fisik, perlengkapan, pegawai, dan saran komunikasi.

\section{Pengertian Kepuasan Pelanggan}

Pelanggan adalah semua orang yang ingin dilayani kebutuhannya sesuai dengan harapannya. Selanjutnya setiap pelanggan pasti ingin mencapai tingkat kepuasan yang dinginkan. Dalam Kotler (2007), secara umum, kepuasan adalah perasaan senang atau kecewa seseorang yang berasal dari perbandingan antara kesannya terhadap kinerja atau hasil suatu produk dan harapan-harapannya. Kepuasan merupakan fungsi dari kesan kinerja dan harapan. Jika kinerja memenuhi harapan, pelanggan merasa puas dan sebaliknya. Kotler (2007) mengungkapkan kepuasan adalah perasaan senang atau kecewa seseorang yang berasal dari perbandingan antara kesannya terhadap kinerja (atau hasil) suatu produk dan harapan harapannya.

Lovelock dan Wright (2007) menyatakan bahwa, kepuasan adalah keadaan emosional, reaksi pascapembelian mereka, dapat berupa kemarahan, ketidakpuasan, kejengkelan, netralitas, kegembiraan dan kesenangan. Kepuasan dipengaruhi oleh perbandingan layanan yang dipahami dengan pelayanan yang diharapkan, dan sebagai reaksi emosional jangka pendek pelanggan terhadap kinerja pelayanan tertentu. Indikator untuk mengukur kepuasan pelanggan adalah: 1 . Kesesuaian kualitas pelayanan dengan tingkat harapan. 2. Tingkat kepuasan apabila dibandingkan dengan yang sejenis 3. Tidak ada pengaduan atau komplain yang dilayangkan.

Menurut Kotler (2007), "Satisfactionreflects a person's 
judgements of a product's perceivedperformance (or outcome) in relationship to expectation"yang berarti kepuasan merupakan perasaan senang atau kecewa yang dihasilkan dari perbandingan performanceproduk terhadap ekspektasi mereka. Jika performance gagal memenuhi ekspektasi, maka pelanggan menjadi tidak puas. Jika performance sesuai dengan ekspektasi, maka pelanggan menjadi puas. Jika performance melebihi ekspektasi, maka pelanggan merasa sangat puas.

Nilai harapan dibentuk melalui pengalaman masa lalu, komentar atau saran dari konsumen dan informasi dari pesaing. Adapun nilai persepsi adalah kemampuan perusahaan dalam melayani konsumen dalam upaya memuaskan konsumen.

Kepuasan pelanggan dapat didefinisikan secara sederhana sebagai suatu di mana kebutuhan, keinginan dan harapan pelanggan terpenuhi melalui produk yang dikonsumsi. Salah satu cara agar kepuasan pelanggan tercapai yaitu dengan meningkatkan kualitas pelayanan dari perusahaan itu sendiri.

\section{TeknikPengukuran}

KepuasanKonsumen

Menurut Philip Kotler (2007) yang dikutip oleh Fandy Tjiptono (2010), untuk mengukur kepuasan pelanggan dapat dilakukan dengan cara: 1. Directly reparted satisfaction. Ungkapan yang disampaikan secara langsung tentang kepuasan dirinya terhadap pelayanan yang diterimanya. 2 . Derived dissatisfaction, Responden diberi pertanyaan mengenai seberapa besar mereka mengharapkan suatu atribut tertentu dan seberapa besar yang mereka rasakan 3. Problem analysis Responden diminta untuk menuliskan masalah-masalah yang mereka hadapi berkaitan dengan penawaran dari perusahaan. Disamping itu responden juga diminta untuk menuliskan perbaikanperbaikan yang mereka sarankan 4. Importance/performance ratings Responden dapat diminta untuk meranking berbagai elemen (atribut) dari penawaran berdasarkan derajat pertanyaan setiap elemen dan seberapa baik kinerja perusahaan dalam masingmasing elemen.

Faktor - faktor yangMempengaruhi KepuasanKonsumen

Menurut Zheithaml and Bitner (2003) ada beberapa faktor yang mempengaruhi kepuasan pelanggan, antara lain: 1. Fitur produk dan jasa. Kepuasan pelanggan terhadap produk atau jasa secara signifikan dipengaruhi oleh evaluasi pelanggan terhadap fitur produk atau jasa. 2. Emosi pelanggan. Emosi juga dapat mempengaruhi persepsi pelanggan terhadap produk atau jasa. Emosi ini dapat stabil, seperti keadaan pikiran atau perasaan atau kepuasan hidup. Pikiran atau perasaan pelanggan (good mood atau bad mood) dapat mempengaruhi respon pelanggan terhadap jasa.

\section{Kerangka Pemikiran}

Berdasarkan kepada landasan teori dan pengembangan hipotesis dan tinjauan penelitian terdahulu dapat disimpulkan adanya pengaruh yang terbentuk antara kualitas pelayanan terhadap kepuasan nasabah, dapat dilihat pada gambar di bawah ini. 


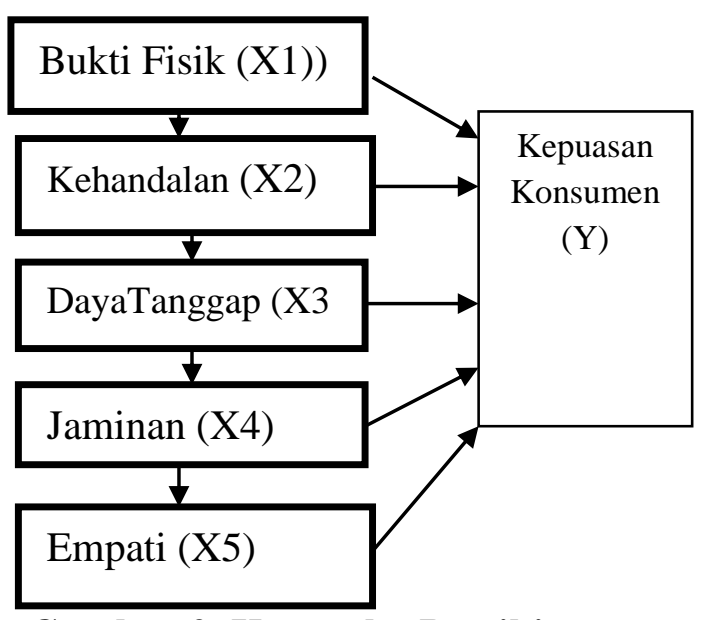

Gambar 2. Kerangka Pemikiran

Sumber : Data Olahan (2018)

Dari penjelasan di atas, maka ditarik hipotesa - hipotesa yaitu : Diduga kualitas pelayanan berpengaruh signifikan terhadap kepuasan konseumen dalam menggunakan jasa penginapan pada Kharisma Hotel Bukittinggi.

\section{METODE PENELITIAN Jenis Penelitian}

Desain penelitian ini menggunakan desain penelitian kausal, penelitian kausal adalah salah satu tipe penelitian konklusif dimana mempunyai tujuan utama untuk mengetahui dan memperoleh bukti mengenai hubungan sebab-akibat (Sirait, 2016). Tujuan dari penelitian kausal ini adalah untuk mengetahui mana yang merupakan variabel independen dan mana yang merupakan variabel dependen dan mencari hubungan di antara variabel independen dengan variabel dependen. Hubungan sebabakibat pada penelitian ini untuk mengungkapkan pengaruh kualitas layanan terhadap kepuasan konsumen Menggunakan Jasa Penginapan pada Kharisma Hotel Bukittinggi. Pendekatan penelitian yang digunakan dalam penelitian ini adalah metode penelitian kuantitatif. Metode penelitian kuantitatif menekankananalisisnya pada data-data numeric (angka) yang diolahdengan metode statistika. Pendekatan kuantitatif biasanya dilakukan pada penelitian inferensial dan menyandarkan kesimpulan pada pengujian hipotesis.

\section{Populasi dan Sampel}

Populasi pada penelitian ini adalah Pelanggan yang menggunakan Jasa Penginapan pada Kharisma Hotel Bukittinggi mulai 1 Januari 2014 hingga 31 Desember 2016 yang berjumlah 1.656 pelanggan. Namun pihak perusahaan tidak dapat memberikan data pelanggan secara rinci untuk penelitian ini dikarenakan alasan rahasia perusahaan. Teknik sampling yang digunakan adalah nonprobability sampling dengan jenis purposive samplin, yaitu teknik penentuan sampel dengan pertimbangan tertentu. Dengan teknik tersebut setiap responden dalam penelitian ini dipilih melalui screeningquestion yaitu dengan menentukan kriteria responden harus sudah lebih dari dua kali menggunakan jasa Kharisma Hotel Bukittinggi. Penentuan sampel menggunakan rumus Slovin sebagai berikut :

$$
\begin{aligned}
& \mathrm{n}=\frac{\mathrm{N}}{\mathrm{N} \mathrm{e}^{2}} \\
& \text { Dimana : } \\
& \mathrm{n}=\text { Ukuran Sampel } \\
& \mathrm{N}=\text { Jumlah Populasi, } 1.656 \\
& \mathrm{e}=\text { Kesalahan dalam pengambilan }
\end{aligned}
$$

$$
\begin{aligned}
n & =\frac{1,656}{1+1.656(0,1)^{2}} \\
& =99,9396499
\end{aligned}
$$$$
\text { sampel, misalnya 10\%, maka : }
$$ 
Berdasarkan perhitungan, maka diperoleh sampel sebanyak 99,9396499 dan dibulatkan menjadi 100 responden. Jadi sampel dalam penelitian ini adalah 100 responden $(n=100)$.

\section{Tabel 1.}

Identifikasi Variabel Penelitian

\begin{tabular}{|c|c|c|}
\hline Klasifikasi & Dimensi & Indikator \\
\hline \multirow{5}{*}{$\begin{array}{l}\text { Variabel } \\
\text { Bebas }\end{array}$} & $\begin{array}{l}\text { Bukti Fisik } \\
\text { (X1)Zeithaml } \\
\text { et al. } \\
\text { (dalamGriselda } \\
\text { dan Panjaitan, } \\
\text { 2007) }\end{array}$ & $\begin{array}{l}\text { a. Bangunan dan } \\
\text { interior yang bagus } \\
\text { dan menarik } \\
\text { b. Kelengkapan } \\
\text { fasilitas yang } \\
\text { ditawarkan } \\
\text { c. Kebersihan dan } \\
\text { kerapian karyawan }\end{array}$ \\
\hline & $\begin{array}{l}\text { Kehandalan } \\
\text { (X2)Zeithaml } \\
\text { et al. } \\
\text { (dalamGriselda } \\
\text { dan Panjaitan, } \\
\text { 2007),Estie } \\
\text { (2006) dan } \\
\text { Husnul } \\
\text { (2010) }\end{array}$ & $\begin{array}{l}\text { a. Memberikan } \\
\text { pelayanan yang } \\
\text { terbaik } \\
\text { b. Jujur dalam } \\
\text { pelayanan } \\
\text { c. Berusaha } \\
\text { menghindari } \\
\text { kesalahan }\end{array}$ \\
\hline & $\begin{array}{l}\text { Daya Tanggap } \\
\text { (X3) } \\
\text { Zeithaml et al. } \\
\text { (dalam } \\
\text { Griselda dan } \\
\text { Panjaitan, } \\
\text { 2007), } \\
\text { Assegaff } \\
\text { (2009) dan } \\
\text { Husnul } \\
\text { (2010) }\end{array}$ & $\begin{array}{l}\text { a.Siap membantu } \\
\text { pelanggan } \\
\text { b. Kecepatan dalam } \\
\text { pelayanan } \\
\text { c. Komunikasi } \\
\text { yang lancar }\end{array}$ \\
\hline & $\begin{array}{l}\text { Jaminan } \\
\text { (X4)Zeithaml } \\
\text { et al. } \\
\text { (dalamGriselda } \\
\text { dan Panjaitan, } \\
\text { 2007),Assegaff } \\
\text { (2009) dan } \\
\text { Husnul(2010) } \\
\end{array}$ & $\begin{array}{l}\text { a. Pelayanan sopan } \\
\text { b. Trampil dalam } \\
\text { melaksanakan } \\
\text { tugas } \\
\text { c. Pengetahuan } \\
\text { memadai }\end{array}$ \\
\hline & $\begin{array}{l}\text { Empati } \\
\text { (X5)Zeithaml } \\
\text { et al. } \\
\text { (dalamGriselda } \\
\text { dan Panjaitan, } \\
\text { 2007),Estie } \\
\text { (2006) dan } \\
\text { Husnul } \\
\text { (2010) } \\
\end{array}$ & $\begin{array}{l}\text { a.Perhatian kepada } \\
\text { konsumen } \\
\text { b. Tanggungjawab } \\
\text { keamanan } \\
\text { c. Mengutamakan } \\
\text { kepentingan } \\
\text { konsumen }\end{array}$ \\
\hline $\begin{array}{l}\text { Variabel } \\
\text { Terikat }\end{array}$ & $\begin{array}{l}\text { Kepuasan } \\
\text { konsumen (Y) } \\
\text { Angelova }\end{array}$ & $\begin{array}{l}\text { a.Kenyamanan } \\
\text { yang dirasakan } \\
\text { konsumen pada }\end{array}$ \\
\hline
\end{tabular}

\begin{tabular}{ll}
\hline (2011) & saat pelayanan \\
& diberikan \\
& b. Keyakinan \\
& konsumen atas \\
pelayananyang & diberikan \\
& c. Minat untuk \\
& selalu \\
menggunakan jasa & d. Perasaan puas \\
& atas perhatian \\
danpelayanan yang \\
diberikan \\
olehkaryawan. \\
\hline
\end{tabular}

Sumber: Data olahan (2018)

\section{Uji Validitas}

Uji validitas digunakan untuk mengukur kevalidan suatu kuesioner penelitian. Secara matemat rumus korelasi Produc Momen :

$r$

$$
=\frac{\mathrm{N}\left(\sum \mathrm{XY}\right)-\left(\sum \mathrm{X}\right) \cdot\left(\sum \mathrm{Y}\right)}{\left.\sqrt{\left\{\left(N \sum X^{2}\right.\right.}-\left(\sum X\right)^{2}\right\}\left\{\left(N \sum Y^{2}\right)-\left(\sum Y\right)^{2}\right\}}
$$

Keterangan :

$r=$ koefisien korelasi product moment

$\mathrm{N}=$ nilai dari item

$\sum_{\chi}=$ jumlah butir soal

$\sum_{\gamma}=$ jumlah total soal

$\sum \mathrm{X}^{2}=$ jumlah skor kuadrat butir soal

$\sum \mathrm{y}^{2}=$ jumlah skor total kuadrat butir soal

Item pertanyaan dalam sebuah penelitian dinyatakan valid apabila $\mathrm{r}$ hitung $>\mathrm{r}$ tabel, di mana rtabel dengan $\alpha=5 \%$.

\section{Uji Reliabilitas}

Alat uji yang digunakan untuk mengukur konsistensi dari alat ukur dalam mengukur gejala yang sama di lain kesempatan dengan program SPSS. Suatu variabel dikatakan reliabel apabila Alpha Cronbach > 0,60. Sedang rumus untuk reabilitas secara statistik dari Spearman adalah :

$$
\mathrm{r} 11=\left[\frac{k}{(k-1)}\right]\left[1-\frac{\Sigma \alpha 2}{\alpha^{2^{\natural}}}\right]
$$

Keterangan :

r 11= Reabilitas instrumen

$\mathrm{k}=$ banyak butir pertanyaan 
$\Sigma \alpha^{2}=$ jumlah varians butir

$\Sigma \alpha \mathrm{t}=$ varian total

$\mathrm{N}=$ jumlah responden

Teknik analisis data yang digunakan adalah analisis regresi linear berganda, karena untuk menguji pengaruh dua atau lebih variabel independent terhadap variabel dependen, yaitu pengaruh antara variable kualitas pelayanan yang terdiri dariReliability, Responsiveness, Empathy,Assurance, dan Tangible terhadap kepuasan konsumen. Dengan skala pengukuran interval atau rasio dalam suatu persamaan linear, pengaruh variabel independen dalam analisis regresi linear berganda dapat diukur secara parsial dan secara bersama-sama yang ditunjukkan oleh coefficients of multipledetermination $\left(\mathrm{R}^{2}\right)$. Adapun model regresi linear berganda adalah sebagai berikut:

$Y=a+b_{1} X_{1}+b_{2} X_{2}+b_{3} X_{3}+b_{4} X_{4}+b_{5} X_{5}$ Uji t

Uji $\mathrm{t}$ digunakan untuk menguji signifikansi pengaruh masing-masing variabel independen (kualitas pelayanan) terhadap variabel dependen (kepuasan konsumen) secara parsial dengan tahapan sebagai berikut :

1. Menentukan Ho dan $\mathrm{Ha}$

2. Ho: $\beta=0$, berarti tidak pengaruh secara parsial antara variabel bebas (wujud fisik, kehandalan, ketanggapan, jaminan kepercayaan, empati) terhadap kualitas pelayanan konsumen.

3. Ha: $\beta \neq 0$, berarti ada pengaruh secara parsial antara variabel bebas (wujud fisik, kehandalan, ketanggapan, jaminan kepercayaan, empati) terhadap kualitas pelayanan

\section{HASIL DAN PEMBAHASAN}

Jika koefisien korelasi item pertanyaan melebihi 0,30 ( $\mathrm{r}$ hitung > 0,300) maka dianggap sudah valid, berikut hasil pengujian validitas dari masing-masing variabel independen dan variabel dependen pada Tabel 2. :

Tabel 2.

Hasil Uji Validitas Variabel Kepuasan Konsumen (Y)

\begin{tabular}{ccccc}
\hline No & $\begin{array}{l}\text { Variabel / } \\
\text { Indikator }\end{array}$ & $\begin{array}{c}\mathbf{r} \\
\text { hitung }\end{array}$ & $\begin{array}{c}\mathbf{r} \\
\text { tabel }\end{array}$ & $\begin{array}{c}\text { Keter } \\
\text { angan }\end{array}$ \\
\hline
\end{tabular}

A. Kepuasan konsumen

\begin{tabular}{lllll}
\hline 1 & 1 & 0.405 & 0.300 & Valid \\
\hline 2 & 2 & 0.658 & 0.300 & Valid \\
\hline 3 & 3 & 0.582 & 0.300 & Valid \\
\hline 4 & 4 & 0.706 & 0.300 & Valid \\
\hline
\end{tabular}

Sumber : Data Olahan (2018)

Berdasarkan Tabel 2 di atas, pengujian validitas dimulai dari uji validitas variabel Kepuasan konsumen (Y) dari 4 butir pertanyaan yang ada, ditemukan semua item Pernyataan valid untuk kepuasan konsumen. Dari hasil uji validitas diperoleh semua nilai korelasi masing-masing lebih besar dari nilai korelasi kritis atau 0.30. Dengan demikian semua item Pernyataan variabel Kepuasan konsumen (Y) dapat digunakan untuk pengujian lebih lanjut.Selanjutnya berikut ini adalah hasil pengujian validitas untuk item Pernyataan pada variabel Kualitas pelayanan (X), akan disajikan pada Tabel 3. berikut ini:

$$
\text { Tabel } 3 .
$$

Hasil Uji ValiditasVariabel Kualitas pelayanan $(\mathrm{X})$

\begin{tabular}{ccccc}
\hline No & $\begin{array}{c}\text { Variabel / } \\
\text { Indikator }\end{array}$ & r hitung & r tabel & $\begin{array}{c}\text { Keterang } \\
\text { an }\end{array}$ \\
\hline A. & $\begin{array}{c}\text { Kualitas } \\
\text { Pelayanan } \\
\text { Dimensi } \\
\text { Bukti Fisik }\end{array}$ & & & \\
\hline 7 & 1 & 0.439 & 0,300 & Valid \\
\hline 8 & 2 & 0.577 & 0,300 & Valid \\
\hline
\end{tabular}




\begin{tabular}{ccccc}
\hline 9 & 3 & 0.473 & 0,300 & Valid \\
\hline B & Kehandalan & & & \\
\hline 10 & 1 & 0.841 & 0,300 & Valid \\
\hline 11 & 2 & 0.660 & 0,300 & Valid \\
\hline 12 & 3 & 0.664 & 0,300 & Valid \\
\hline C & $\begin{array}{l}\text { Daya } \\
\text { Tanggap }\end{array}$ & & & \\
\hline 13 & 1 & 0.351 & 0,300 & Valid \\
\hline 14 & 2 & 0.596 & 0,300 & Valid \\
\hline 15 & 3 & 0.510 & 0,300 & Valid \\
\hline D & Jaminan & & & \\
\hline 16 & 1 & 0.543 & 0,300 & Valid \\
\hline 17 & 2 & 0.604 & 0,300 & Valid \\
\hline 18 & 3 & 0.525 & 0,300 & Valid \\
\hline E & Empati & & & \\
\hline 19 & 1 & 0.770 & 0,300 & Valid \\
\hline 20 & 2 & 0.744 & 0,300 & Valid \\
\hline 21 & 3 & 0.482 & 0,300 & Valid \\
\hline Sum & 1 & &
\end{tabular}

Sumber : Data Olahan (2018)

Berdasarkan Tabel 3. diatas, pengujian validitas dimulai dari uji validitas variabel kualitas pelayanan yang terdiri dari lima dimensi yaitu bukti fisik (X1),kehandalan (X2), daya tanggap (X3),jaminan (X4) dan empati (X5) dari pertanyaan yang ada dinyatakan semuanya valid, karena diperoleh semua nilai korelasi masingmasing lebih besar dari nilai korelasi kritis atau 0.30. Dengan demikian semua item Pernyataan variabel kualitas pelayanan dimensi bukti fisik, empati, daya tanggap, keandalan dan jaminan dapat digunakan untuk pengujian lebih lanjut.

\section{Uji Reliabilitas}

Analisis reliabilitas menunjukkan sejauh mana suatu instrument dapat memberikan hasil pengukuran yang konsisten apabila pengukuran diulang dua kali atau lebih. Metode yang digunakan dalam analisis reliabilitas ini adalah metode Alpha-Cronbach.Nilai Alpha-Cronbach (r alpha) dikatakan handal (reliabel) apabila memiliki AlphaCronbach lebih dari 0,60 (Ghozali :2006).
Table 4. Hasil Pengujian Reliabilitas

\begin{tabular}{lrc}
\hline Variabel & $\begin{array}{c}\text { CronbachA } \\
\text { lpha }\end{array}$ & $\begin{array}{c}\text { Keteranga } \\
\text { n }\end{array}$ \\
\hline $\begin{array}{l}\text { Kepuasan } \\
\text { konsumen }\end{array}$ & 0.867 & Reliabel \\
\hline Bukti Fisik & 0.675 & Reliabel \\
\hline Kehandalan & 0.847 & Reliabel \\
\hline Daya Tanggap & 0.659 & Reliabel \\
\hline Jaminan & 0.728 & Reliabel \\
\hline Empati & 0.808 & Reliabel \\
\hline
\end{tabular}

Sumber : Data Olahan (2018)

Dalam penelitian ini uji reabilitas dilakukan dengan melihat hasil perhitungan nilai cronbach alpha $(\alpha)$. Suatu variabel dikatakan reliabel jika memberikan nilai cronbach alpha $(\alpha)>$ $60 \%$ yaitu bila dilakukan penelitian ulang dengan waktu dan dimensi yang berbeda akan menghasilkan kesimpulan yang sama. Tetapi sebaliknya bila alpha $(\alpha)<60$ maka dianggap kurang handal, artinya bila variabel-variabel tersebut dilakukan penelitian ulang dengan waktu yang berbeda akan menghasilkan kesimpulan yang berbeda.

\section{Analisis Regresi Linear Berganda}

Analisis regresi linear berganda digunakan untuk melihat pengaruh kualitas pelayanan terhadap kepuasan konsumen menggunakan jasa penginapan pada Kharisma Hotel Bukittinggidan sekaligus dalam rangka membuktikan hipotesis yang diajukan dalam penelitian. Pengaruh kualitas pelayanan terhadap kepuasan konsumen. Hasil analisa regresi liner berganda dapat dijelaskan pada Tabel 1.5 berikut: 
Tabel 5.

Hasil Analisis Regresi Berganda

\begin{tabular}{|c|c|c|c|c|c|c|}
\hline \multirow{2}{*}{\multicolumn{2}{|c|}{ Model }} & \multicolumn{2}{|c|}{$\begin{array}{l}\text { Unstandardized } \\
\text { Coefficients }\end{array}$} & \multirow{2}{*}{$\begin{array}{c}\text { Standa } \\
\text { rdized } \\
\text { Coeffic } \\
\text { ients } \\
\text { Beta }\end{array}$} & \multirow[b]{2}{*}{$\mathrm{t}$} & \multirow[b]{2}{*}{ Sig. } \\
\hline & & B & Std. Error & & & \\
\hline \multirow[t]{6}{*}{1} & (Constant) & 39.235 & 6.455 & & 6.079 & .000 \\
\hline & Bukti fisik & .358 & .141 & .213 & 2.534 & .013 \\
\hline & Kehandalan & .255 & .116 & .188 & 2.192 & .031 \\
\hline & Daya tanggap & .534 & .125 & .372 & 4.279 & .000 \\
\hline & Jaminan & .277 & .132 & .169 & 2.094 & .039 \\
\hline & Empati & .677 & .172 & .328 & 3.935 & .000 \\
\hline
\end{tabular}

a. Dependent Variable: Kepuasan

Konsumen

Sumber : Data Olahan (2018)

Kemudian nilai koefisien regresi masing - masing variabel diatas dapat disubtitusikan ke dalam persamaan regresi linear berganda sebagai berikut :

$\mathrm{Y}=39,235+0,358 \mathrm{X} 1+0,255 \mathrm{X} 2+$ $0,534 \mathrm{X} 3+0,277 \mathrm{X} 4+0,677 \mathrm{X} 5$

Dari persamaan tersebut dapat dijelaskan bahwa:

Nilai konstanta sebesar 39,235, ini menunjukkan bahwa kepuasan konsumen sebelum dipengaruhi kualitas pelayanan dengan dimensi Bukti fisik, kehandalan, Daya tanggap, jaminan dan empatisudah ada sebesar 39,235 dengann asumsi variabel lain tetap.

Nilai dari variabel independen yaitu bukti fisik (X1) adalah sebesar 0,358 yang artinya bahwa bukti fisik berpengaruh positif signifikan terhadap kepuasan konsumen, jika bukti fisik dinaikkan satu satuan maka kepuasan konsumen akan meningkat sebesar 0,358. Kemudian kehandalan (X2) nilainya sebesar 0,255 yang artinya bahwa empati berpengaruh positif signifikan terhadap kepuasan konsumen, jika empati dinaikkan satu satuan maka kepuasan konsumen akan meningkat sebesar 0,255. Kemudian variabel independen ketiga dari dimensi kualitas pelayanan adalah daya tanggap (X3) nilainya sebesar 0,534 yang artinya bahwa daya tanggap berpengaruh positif signifikan terhadap kepuasan konsumen, jika daya tanggap dinaikkan satu satuan maka kepuasan konsumen akan meningkat sebesar 0,534. Variabel keempat independen adalah jaminan (X4) nilainya sebesar 0,277 yang artinya bahwa keandalan berpengaruh positif signifikan terhadap kepuasan konsumen, jika keandalan dinaikkan satu satuan maka kepuasan konsumen akan meningkat sebesar 0,277, dan yang terakhir variabel independen dimensi kualitas pelayanan adalah empati (X5) nilainya sebesar 0,677 yang artinya bahwa jaminan berpengaruh positif signifikan terhadap kepuasan konsumen, jika jaminan dinaikkan satu satuan maka kepuasan konsumen akan meningkat sebesar 0,677.

Hasil analisa statistik deskriptif memperlihatkan bahwa rata-rata total capai responden variabel kepuasan konsumen pengguna jasa penginapan pada Kharisma Hotel Bukittinggi masih taraf sedang belum sampai ketahap sangat baik, untuk itu ini merupakan tugas menejer untuk mensosialisaikan kepada bawan agar meningkatkan kualitas pelayanan di Kharisma Hotel Bukittinggi demi untuk menciptakan loyalitas konsumen dan kepuasan konsumen.Kemudian dari segi bukti fisik yang di tawarkan Kharisma Hotel Bukittinggi terhapa konsumen yang menggunakan jasa penginapan termasuk dalam kategori sangat baik, karena dari hasil penelitian penulis Kharisma Hotel memiliki fisik yang bagus dan terletak di jantung kota Bukittinggi dan juga memiliki lapangan parkir yang luas sehingga pantas konsumen memberikan jawaban sangat baik, keandalan di 
Kharisma Hotel ini sudah termasuk baik semoga dapat ditingkatkan lagi kedepannya tau minimal dapt dipertahankan. Ketiga adalah daya tanggap yang diterapkan Kharisma Hotel Bukittinggi juga masih kurang baik sehingga tanggapan responden tentang daya tanggap ini masih sedang juga, untuk itu perlu ditingkatkan lagi oleh pihak hotel demi kebaikan hotel kedepannya, dan jaminan yang diberikan pihak Kharisma Hotel Bagi para konsumen yang menggunakan jasa penginapan ini sudah termasuk baik semoga dapat dipertahankan kedepannya. Kemudian kualitas pelayanan yang kelima adalah empati yang diharapkan konsumen dari para karyawan hotel adalah empati yang tinggi, dari penelitian yang dilakukan bersamaan dengan hasil penelitian Januar, P. E. (2016), Kusuma Wijayanto (2015) dan Purwati \& Setiawan (2018) dimana ditemukan hasil bahwa empati berpengaruh terhadap kepuasan konsumen.

\section{PENUTUP}

\section{Kesimpulan}

Berdasarkan hasil penelitian yang dilakukan penulis pada Kharisma Hotel Bukittinggimaka dapat dikemukakan kesimpulan : bahwa kualitas pelayanan yang terdiri dari bukti fisik, kehandalan, daya tanggap, jaminan dan empati memiliki pengaruh positif dan signifikan terhadap kepuasan konsumen yang menggunakan jasa penginapan pada Kharisma Hotel Bukittinggi, hal ini sejalan dengan penelitian Nilasari, E., \& Istiantin (2015).

\section{Saran}

Penelitian ini diharapkan dapat menjadi bahan perbaikan bagi manajemen hotel Kharisma untuk dapat meningkatkan kualitas layanan yang ada demi menarik minar dari para pelanggan. Selain itu, penelitian selanjutnya dapat mengembangkan penelitian ini melalui variabel-variabel yang lebih baru lagi atau dengan menambahkan loyalitas pelanggan sebagai variabel terikat lainnya.

\section{DAFTAR PUSTAKA}

Januar, P. E. (2016). Pengaruh Kualitas Pelayanan Terhadap Kepuasan Pelanggan Pada Jne Cabang Bandung. Jurnal Manajemen, 11(2), 265-289.

Kotler, Philip, (2007), Manajemen Pemasaran, Jilid 2, Edisi 12, PT Indeks., New Jersey.

Kusuma Wijayanto. (2015). Pengaruh Kualitas Pelayanan Terhadap Kepuasan dan Loyalitas Pelanggan. Jurnal Paradigma, 17(1), 38-45.

Lovelock, Christoper. \& Wright, Lauren, K. (2007). Manajemen Pemasaran Jasa, PT. Indeks, Indonesia.

Nilasari, E., \& Istiantin. (2015). Pengaruh kualitas pelayanan terhadap kepuasan konsumen pada dealer PT. ramayana motor sukoharjo. Jurnal Paradigma, 13(1), 1-12.

Purwati, A., \& Setiawan, O. (2018). Analisis Pengaruh Kualitas Pelayanan, Kepuasan dan Insentif terhadap Perilaku Word Of Mouth Mahasiswa STIE Pelita Indonesia. Journal of Economic, Bussines and Accounting (COSTING), 1(2), 124-136. https://doi.org/https://doi.org/10.31 539/costing.v1i2.207

Sirait, J. N. (2016). Pengaruh Kualitas Pelayanan Terhadap Kepuasan Pelanggan pada Waterpark Perum Bumi Sempaja di kota Samarinda. 
Ejournal Administrasi Bisnis, ISSN: 2355-5408, 4(2), 342-355. https://doi.org/10.1017/CBO978110 7415324.004

Sulistyawati, N. M. A., \& Seminari, N. K. (2015). Pengaruh Kualitas Pelayanan Terhadap Kepuasan Pelanggan Restoran Indus Ubud Gianyar, 4(8), 2318-2332.

Tjiptono, Fandy.2007, Strategi Pemasaran. Edisi ke dua, penerbit Andi,. Yogyakarta

Zeithaml dan Bitner. (2003). Service Marketing Integrating Customer Focus Across the Firm, 3 rd edition. 